reports which have been prepared since 1947 readily obtainable. Complete sets are also being presented to a number of other countries and to certain international agencies. In addition to this, the Authority is increasing its facilities for supplying reports in conventional form as they are prepared. From February 16 a large number of unclassified and declassified reports, which have hitherto been obtainable only on loan from Atomie Energy Authority libraries, will be available in micro form. Arrangements have been made with Micro Methods, Ltd., of East Ardsley, Wakefield, Yorks, for the production of microcopies on card of all unclassified and declassified reports issued between 1947 and December 1956 and, on a continuing basis, of those reports issued since 1956 which are not available on sale from H.M. Stationery Office. Microcopies may be purchased from Micro Methods.

\section{Sands of Forvie Nature Reserve}

SANDS of Forvie, Aberdeenshire (1,774 acres), which has been declared a new Nature Reserve by the Nature Conservancy, under an agreement with the Walker Scottish Estates Co., Ltd., the owners, lies on the coast near Newburgh, between the mouth of the River Ythan and the village of Collieston. It consists of a broad foreshore backed by a line of dunes, behind which are slacks and more stable dunes passing inland to dune heath and rough pastures. To the north of the low sandy shore and the seaward dunes there are cliffs of schists and gneisses overlain by boulder clay. This rocky part of the coast includes Hackley Head and Hackley Bay. Inland from Collieston are two small freshwater lochs-Sand Loch and Cotehill Loch.

The chief botanical interest lies in the plant communities of the dunes. Marram grass (Ammophila arenaria) is the dominant species on the shifting dunes, while the sand sedge (Carex arenaria), the jointed rush (Juncus articulatus) and silver weed (Potentilla anserina) are generally among the earliest established dominants on the sheltered, moist dune plains. Mat grass (Nardus stricta), crowberry (Empetrum nigrum), creeping willow (Salix repens), crossleaved heath (Erica tetralix) and ling (Calluna vulgaris) become prominent in later stages of the succession inland to the fixed dunes. The crowberry plants, conspicuous over large areas, are usually associated with lichens, forming a distinctive $\mathrm{Em}$ petrum-lichen heath community. The lesser spearwort (Ranunculus flammula) and the toad rush (Juncus bufonius) are characteristic of the wetter dune hollows which are often locally rich in mosses. Birds breeding within the area include eider (a particularly large nesting population), shoveller, shelduck, red grouse, little tern, arctic tern, common tern, sandwich tern, and fulmar. The whole area offers excellent opportunities for developing physiographical and biological observation and research. Among the dunes there are important Late Bronze and Farly Iron Age sites which have yielded stone implements and pottery, and comprising stone circles, a flat ring cairn and kitchen middens.

\section{Microbiological Defence Research}

Is reply to a question in the House of Commons on January 26 regarding the Microbiological Research Centre and the Chemical Defence Experimental Establishment, the Minister of Supply, Mr. A. Jones, said that the Ministry of Supply Establishments at Porton are mainly engaged in research on defensive problems of microbiological and chemical warfare. The investigations are essentially directed towards assessing the threat and providing defences against it, and most of the results obtained are published in the scientific literature. The danger from botulinus toxin is included, but this danger has been grossly exaggerated, since the toxin cannot be easily disseminated and is not self-propagating. Useful defensive measures against it are known.

\section{Scientific Research in South African Universities}

THE Register of Current Scientific Research at South African Universities, 1957 (pp. viii +198. Pretoria: South African Council for Scientific and Industrial Research, 1958), is the fifth of the series of annual volumes listing research projects in the natural sciences being undertaken at South African universities and intended to meet the needs of research workers in South Africa and elsewhere. The information is given in the language in which it was received from the universities, but an English translation of Afrikaans entries is provided, and the alphabetical order of the subject-matter is determined by the English heading. As in previous volumes, entries are grouped under subjects, corresponding roughly with departmental divisions in the universities, and under these headings are arranged all the research projects in that subject in each university in turn. There are also an author and a subject index.

\section{The Nucleus}

IN view of the spectacular advance made in recent years in the field of genetics, there is a growing need for more information about the physical basis of genetic phenomena. The Nucleus, an international journal of cytology and allied topics, recently published, has this aim (The Nucleus, 1, No. 1; June 1958. Pp. 152. Calcutta: Dr. A. K. Sharma, Editor, Botany Department, The University, 1958; annual subscription 10.50 dollars or Rs. 46.00) The contributions in the first issue deal with descriptive cytology, chromosome dynamics, chemical and radiation effects on chromosomes and the mitotic process, and include a scholarly study on the possible role of nuclear membrane detachment in cytoplasmic organization. The international advisory board consists of H. Kihara (Japan), H. P. Riley, B. P. Kaufmann and J. H. Taylor (United States), F. Oehlkers (Germany), A. Löve (Canada) and M. J. Sirk (Holland). The editor is Dr. A. K. Sharma. The style of printing and the photographic reproductions can compare favourably with any other well-established publication.

\section{Fourth Congress on Theoretical and Applied Mech. anics}

THE fourth Congress on Theoretical and Applied Mechanics was held at the Bengal Engineering College, Howrah, during December 28-31, under the presidency of Dr. S. R. Sen Gupta, director of the Indian Institute of Technology, Kharagpur. About two hundred and fifty scientists and engineers, including members from Australia, Burma, Czechoslovakia, Egypt, Hungary, Italy, Japan, Poland, the United States and the U.S.S.R. attended. Some forty original papers were read, on subjects including finite deformation, visco-elasticity, stress waves, stresses in strips, columns and disks, plasticity, elasto-porosity, vibration and stability, fluid-flow, ballistics and statistics. 